\title{
The Raploch: A history, people's perceptions and the likely future of a problem housing estate
}

\begin{abstract}
This article explores the experience of belonging and identity, and the social distance and separateness which has long characterised aspects of Stirling's Raploch housing estate. Detailed historical archive work uncovered the limited social planning and architectural ambitions set for this housing estate, when compared to the earlier Riverside development. The consequences of such decision making and subsequent poor management of the estate is then articulated through a series of qualitative interviews which explore attitudes to the construction and sustaining of neighbourhood and community identities. Achieving a physical solution to Raploch's social problems has eluded a series of recent regeneration initiatives and this paper suggests that the core problem is not primarily architectural but rather one of class-related discrimination and stigma which has been core to Raploch's identity since the 16th Century.
\end{abstract}

\section{The Ra P L OCH : In TRODUCTION}

It would be difficult to exaggerate the significance of council housing in the history of twentieth-century Scotland. Emerging out the collective efforts of the 'Great War', the original ambition set for council housing was summed up in the promise of 'Homes fit for Heroes'. In effect, given the obvious failings of the private sector, the State was taking responsibility for housing working class families. Despite economic recession and subsequent fiscal retrenchment this ambition was never completely abandoned during the inter-war period and with the development of the Welfare State after World War Two the commitment to council housing became part of the national consensus. The apogee of this effort was reached by the mid i 970 s when, for the whole of the United Kingdom, one third of the entire population was by then accommodated in council housing. ${ }^{.}$In Scotland the proportion was far higher at two thirds. ${ }^{2}$ Since then council housing has changed dramatically, in that it now houses those who previously had been effectively excluded from it, namely the poor, the homeless, the disabled and minorities, and working class families no longer view council housing as the tenure of choice; today less than a third of the population reside in council housing. ${ }^{3}$ Whether such housing is loved or loathed, it is not possible simply to ignore the impact council housing has had on the social and physical landscape of Scotland. 
This paper is based upon a study of housing neighbourhoods and social class identity which was funded by the Joseph Rowntree Foundation. ${ }^{4}$ Three distinctive and contrasting Stirling neighbourhoods were examined, all of which were constructed during the interwar period. One of these, the smallest, was a private housing development located beside Stirling Royal Infirmary (referred to in the study as 'Randolph Road'). The other two were council schemes: Riverside, comprising the first council houses built in Stirling, in the immediate post-war flush of enthusiasm and subsequently inhabited by both 'white collar' middle classes and respectable 'blue collar' working class families; and Raploch, built only a short while later, under very different circumstances, as part of clearance procedures focused on the medieval slums located immediately below Stirling Castle.

Our concern here is with this latter development. 'The Raploch', as it is so often referred to, is one of Scotland's archetypal 'problem' housing estates. Such estates or council schemes have long received widespread media attention which, in turn, has provoked public responses. The study arose, in part, from a recognition that so many initiatives to 'regenerate' such problem estates have failed, with the Raploch being a prime example, and a concomitant recognition that the reputation attached to housing schemes have a marked longevity and resilience. So despite often massive investment programmes to rectify perceived physical and social problems these have had a limited impact because the actual and relative reputation of such areas is usually left untouched.

To many, council housing may at first sight appear to have little to contribute to Scotland's architectural heritage. Its significance, however, lies not only in the sheer enormity of the various building programmes (between 1920 and 1978 the public sector built over one million houses in Scotland), ${ }^{5}$ but also with the ways in which this housing dramatically altered both the physical and social landscape of Scotland's towns and cities. Housing clearly determines the physical and social aspects of any neighbourhood, whether it be nineteenth century suburban villas, or twentieth century council housing, or twentyfirst century two-bedroom, 'luxury' private apartments. Whoever, at a particular point in time, resides in that housing is core to defining a neighbourhood's distinct social class identity. Describing a neighbourhood as 'nice', is as much a reflection of who stays there, as it is of the housing and its locality; and just how often does one hear the term 'council housing' used pejoratively?

The Raploch : A History

What we know as Raploch today is essentially a twentieth century council housing creation, with the first of the various development 'schemes' dating from 1928 , and the others taking place in the 1930s, 1950s, 1970s and, currently, in the 2000 s. Raploch does, however, have a much longer history and three centuries ago it could have been depicted as a rural idyll.

The lands of Raploch had been owned by the Scottish Crown, and then the Earl of Mar, from whom they were purchased by the Burgh Council of Stirling, through the Cowane's 


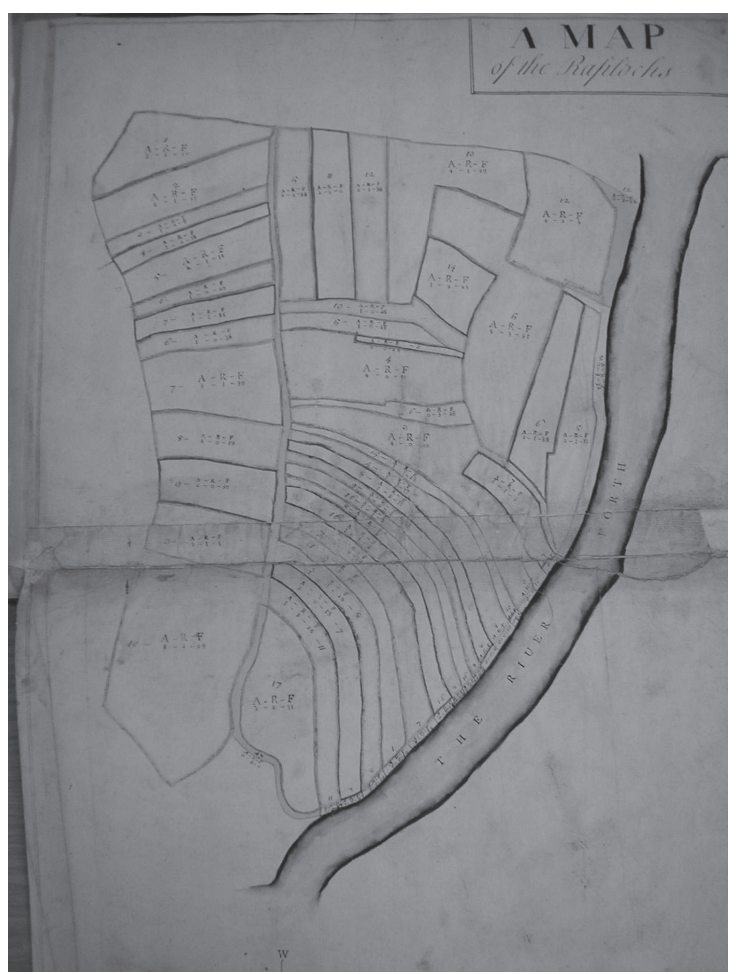

5. I Early Raploch Fueing Plan, I 759 (Source: Stirling Council Archive, MP/SB/35)

Hospital Trust, in $1677 .{ }^{6}$ In the final years of the seventeenth century, during the years of death and famine, the Burgh Council decided to encourage salmon fishing on the Forth by feuing fourteen acres of Raploch into a series of two acre holdings (Figure 5.I). This early example of local economic development did not last long as records soon after indicate that wealthy inhabitants, such as burgesses of the town, now owned the salmon fishing cottages at Fishers' Row and were sub-letting them.

At the end of the eighteenth century, in the spirit of 'improvement', the Cowane's Trust re-organised the lands of Raploch into a single large farm, and built a small village, to be inhabited mainly by artisans. The Census of I 84 I reveals a population of 3 I 7 people, with the most significant occupational group being in textiles and clothing. Nearly everyone was Scottish born, with only nine of the village being Irish. Ten years later the ${ }_{5}{ }_{5}$ I Census shows that the Irish population had expanded to 85 ( 23 per cent), a consequence of the widespread Irish migration to Scotland brought about by the Potato Famine of i 845 . They were attracted to Stirling by the rapid growth of mining work in the Stirlingshire coal fields. From this date the long lasting association of the Irish and Raploch was established. Shortly after, Raploch was described in an official account as an 'Irish village', and it was also reputed 
that when the 'Irish' went away on their annual bark-stripping work - bark being used in the local tanneries - the crime rate in Stirling fell substantially. ${ }^{7}$ In such stories and events, accurate or not, we find the basis of enduring myths and understandings of this particular locale and its identity. While there were some local figures prepared to see the inhabitants, including the Irish, in a more positive light, negative accounts were always more usual, such as the following from the i 870 :

If any one should take a walk along the Raploch any of these good days ... he will find there at all times of the day a number of able-bodied men squatting on the green sward on the road side, some lying on back, some on belly, some on side, some half-sitting with pipe in mouth and all glabbering away in the Connaught brogue. ${ }^{8}$

\section{Thentieth Century Raploch}

The construction of the inter-war 'slum clearance' estate, which allowed for the clearance of medieval 'Tap o'Toun' slums, ensured another influx of Irish and other poor families who had long resided in Stirling's notorious slum district. As a result, social distance was further reinforced and has been a constant feature of The Raploch ever since. Initially the estate was seen as a site of poverty and unemployment and from the i 970 s it became a locality of 'multiple social deprivation', now repackaged as 'social exclusion'. An associated reputation for petty crime, drunkenness, violence, and more recently drugs, has long hung over Raploch and its residents. In response to these social problems, a variety of publicly funded initiatives have been focused on the area, involving housing investment and social work programmes drawing on both local authority and central government monies. Yet, despite thirty years of such investment the Raploch is still the poorest and most deprived neighbourhood in central Scotland. ${ }^{9}$ Ironically, given the scale of this investment, the Raploch is simultaneously the poorest and least desirable, yet most expensive real estate within Central Scotland. The Raploch is currently entering another phase of regeneration, its fourth in the last thirty years.

As a relatively wealthy town, Stirling's housing conditions were, in terms of overcrowding, better than the Scottish average and when compared to the other large burghs. ${ }^{10}$ Nonetheless, by the early years of the twentieth century there was a recognition that Stirling's main social problem was the poor condition of housing, mainly in the 'Tap o'Toun'. It was not, however, until after the First World War that any serious attempts were made to improve the housing of Stirling's working classes. At a full council meeting in December r 9 I 8 it was decided to 'adopt the recommendation of the Local Government Board and construct the houses of two or three bedrooms with living room and scullery and bathroom with hot and cold water'. "' After continuing debates, the initial council houses were ready by October 1 $920 .{ }^{12}$ This was 'Shiphaugh', one of Scotland's earliest council schemes, which was located within the Riverside area. These and the subsequent houses in 
Riverside were built as an exemplar of good quality, high specification, if slightly utilitarian housing. ${ }^{13}$ By the late 1920 s, however, there was a growing recognition that council housing was failing to address the needs of the bulk of the labouring population. ${ }^{14}$

Raploch provided a ready-made solution; it was flat, relatively close (but not too close) to the town centre with plenty of room for future expansion and the land was effectively owned by the town. Huge tracts of Stirling land were under the control of the Cowane Hospital Trust, the members of which were essentially the town councillors. As early as I 925 the Burgh purchased land in Raploch from the Trust with the intention of building council houses on it. ${ }^{15}$ A Raploch resident comments that:

Ah think whit made it a rough area, they had nothin'. An' ah think they shoved a' the rubbish doon there. Ah mean a lot o' them used tae live up the top o' the toon at one time. An ah think it wis because people had nothin' - they's hae their wee fights an' that, ay, but it wis like an auld minin' community. Ye'd hae yer wee battles, they werenae bad (Male 63: Raploch).

In order to construct houses that lower paid workers could afford to rent, the Council had to build them smaller and to less exacting standards. Against the advice of the local Sanitary Inspector and the Scottish Office, cost-cutting measures such as reducing the thickness of party walls and reducing the number of bedrooms meant that these houses would always fall short of Riverside standards. As the Council's own plans from 1927 clearly show, the early Raploch schemes were to be predominantly two and three apartments (which meant one and two bedrooms). ${ }^{16}$ In 1930 , the Council received a communication from the Department of Health regarding the specification of the next phase of the Raploch scheme 'pointing out their disapproval of two apartment houses ... and the desirability of larger houses'. ${ }^{\text {I7 }}$ As predicted, it was soon apparent that many very large families were housed in such small properties, thus ensuring overcrowding was an issue which persisted throughout the twentieth century (Figure 5.2).

As early as the mid- I93os, particularly those in the Thistle Housing Trust who wished to preserve the old medieval tenements around the Castle were giving warnings about the danger of constructing the slums of the future. At a fund-raising event held for the Trust, the point was made that the houses they were refurbishing had already existed for hundreds of years, and would last for 'hundreds of years yet, when the "'new slums" by public bodies had gone.' ${ }^{18}$ By 1936 , even the Burgh's own Medical Officer of Health was drawing attention to the overcrowding that was 'becoming almost as common in the housing schemes as in the slums'. ${ }^{19}$

Most of Raploch was designed in-house by the Council through the offices of the Burgh Engineer. At the same time there was an effort when building the later Coronation Blocks in 1936 for Scottish baronial vernacular to be incorporated into the design (Figure 5.3). It is perhaps ironic that the architect of the Coronation Blocks, Eric S. Bell, was also the inhouse architect of the Thistle Trust. ${ }^{20}$ Though reminiscent of municipal housing elsewhere 


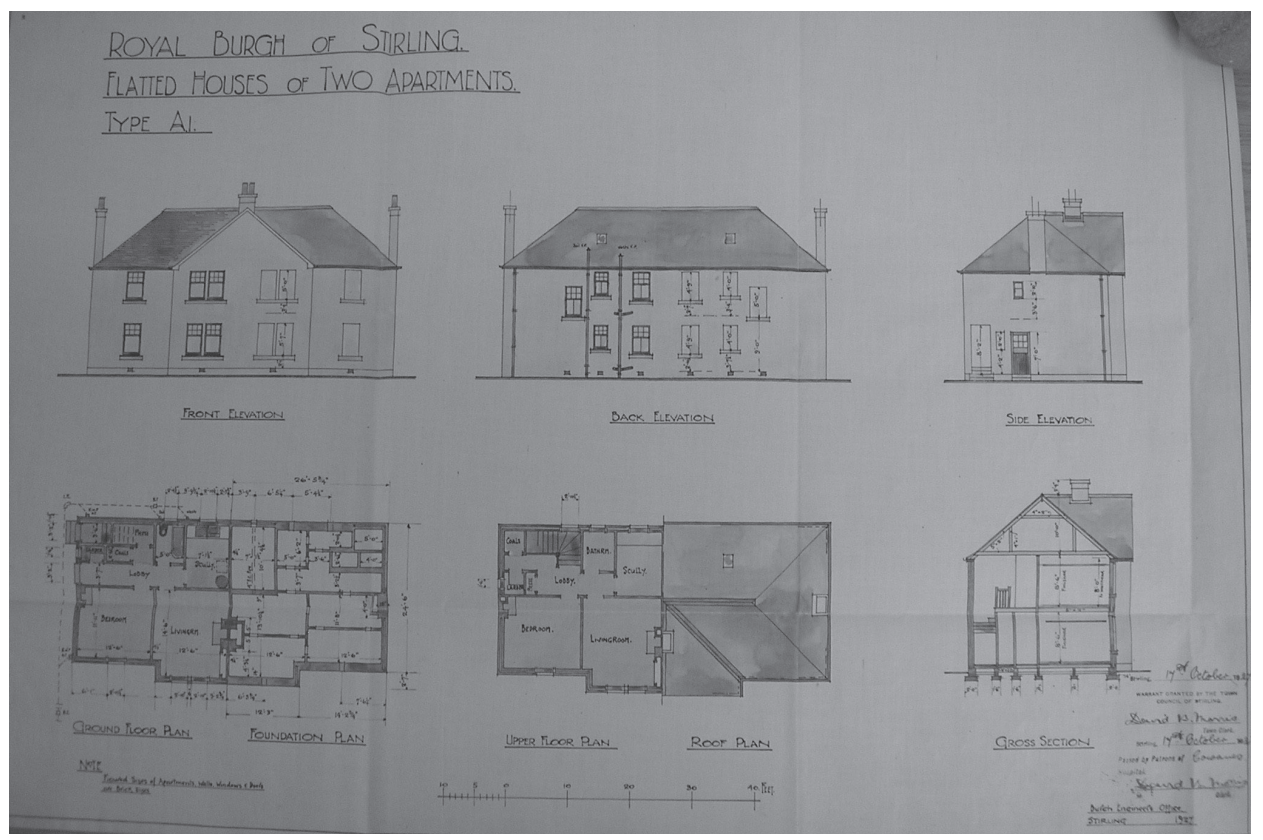

5.2 Raploch Council House Plan 1927 (Source: Stirling Council Archive, MP/SB4/3/ I 2 / I 9 I 5 )

in Scotland, the Coronation Blocks were merely a one-off to celebrate the accession of George IV. Bell was not, as some seem to think, the original architect of Raploch but was responsible for 66-74 Drip Road only. It would be wrong to identify housing in Raploch in any way as pioneering or exemplary on the basis of what is a minute - if physically prominent and architecturally worthy - part of the scheme.

Many of Raploch's new tenants came directly from the most insanitary housing within the Burgh, especially the tenements at the 'Tap o'Toun', but also from St Ninians, another mining community. As the famous г 9 I 7 Royal Commission report noted mining villages represented some of Scotland's worst housing environments. ${ }^{21}$ A large number of the incomers and previous residents were miners, with some Raploch streets almost exclusively tenanted by such men and their families. As a Raploch resident recalls:

In they days ah wid say the biggest majority, but don't call it a mining village, but the biggest majority were miners, cos there used tae be two buses came in the mornin'. One at twenty to six an' one at ten to six. Was miners cos there are a awful lot of miners... (Male 63: Raploch).

In the immediate post- I 945 period, Raploch expanded east of the Drip Road onto what were the old army parade grounds that lay immediately below the Castle. This flat roofed Orlit housing, of a 'non trad.' construction, did not prove popular, however, and became 


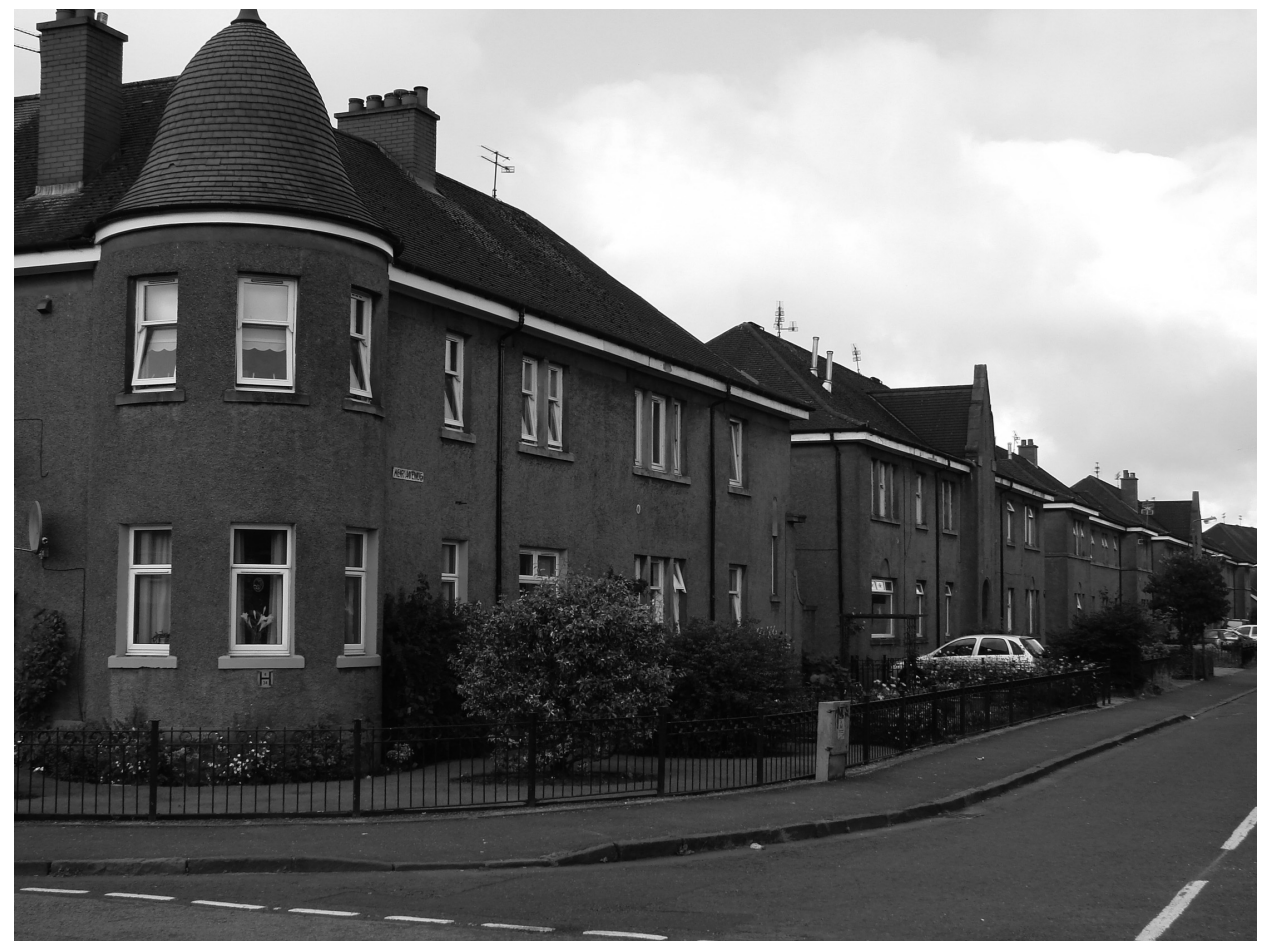

5.3 Weir Avenue, Raploch (Source: Douglas Robertson)

hard-to-let from the late i 960 s onwards. Non traditional housing was common in the years immediately following the Second World War when local authorities, keen to build new property to deal with the massive housing shortage and the fact that traditional building materials were, at that time, in short supply resorted to using new construction methods for speed and economy. ${ }^{22}$ As the scheme expanded the reputation of the area remained as bad as ever, if not worsening. By г 973, The Architects' Journal commented that, 'Today, Raploch is a social and environmental disaster area. ${ }^{23}$

There were at that time a few small infill developments of the 'fishing village' genre favoured by architects in the igjos, before the estate underwent whole scale renewal involving council funded housing and environmental improvements, a process that has subsequently occurred twice, with a new phase about to start as part of the latest regeneration initiative. ${ }^{24}$ Part of this initial work has involved extensive demolition of the Orlits, which, despite various renewal and letting initiatives, always remained very unpopular (Figure 5.4). The most infamous of these was the Glendevon Lettings Initiative, which ran from the late i 980 os through to early i 990 s. By reducing the points needed to secure a house, a highly transient and problematic population was attracted into the area, resulting in major estate management issues and a complete social collapse of that part of the 


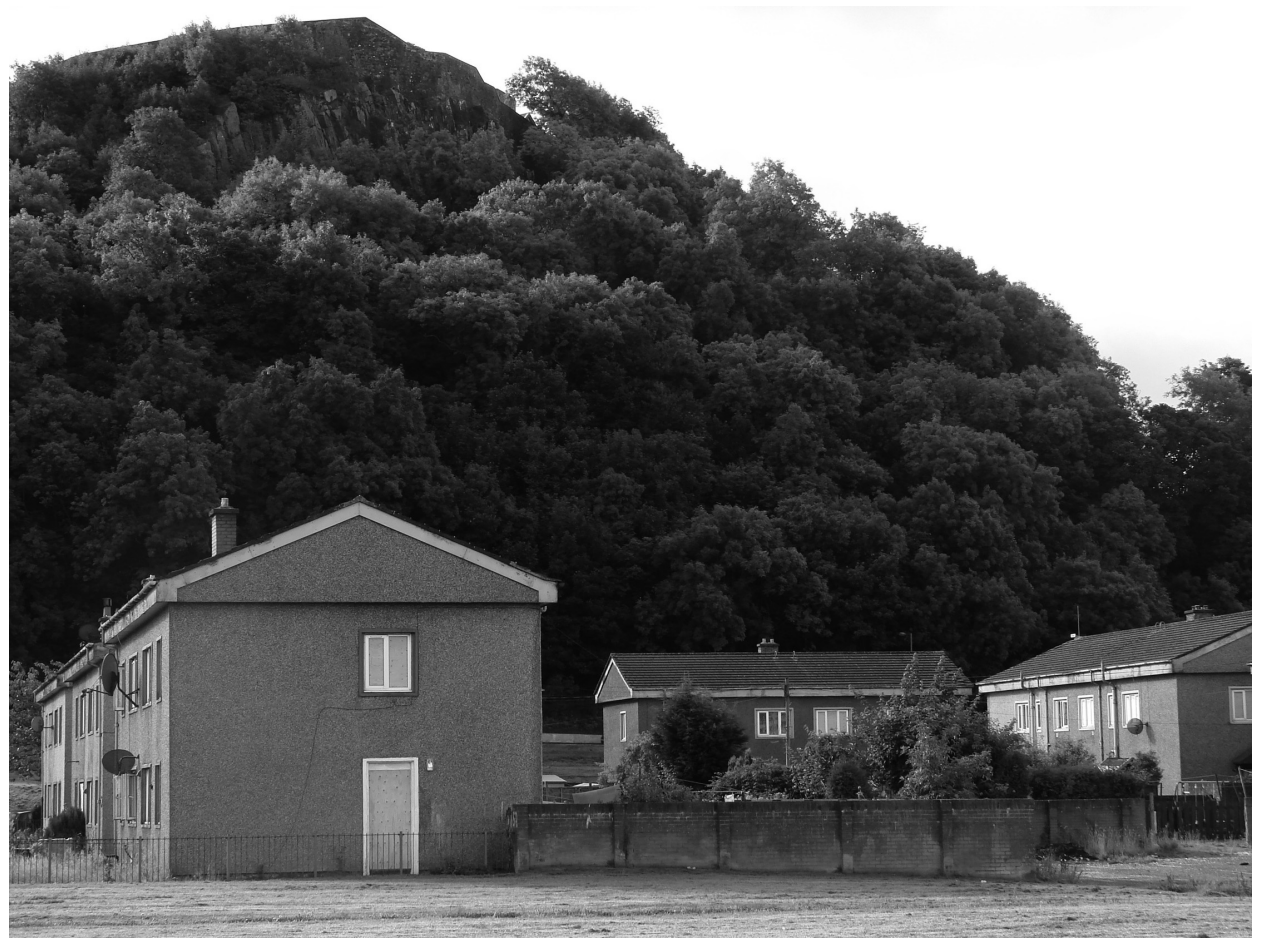

5.4 Raploch Orlit housing, Glendevon awaiting demolition, 2007 (Source: Douglas Robertson)

estate. This site will now be completely redeveloped, largely for private housing, so again there is the prospect of creating a 'new' Raploch, cheek by jowl next to the 'old' Raploch in both a physical and social sense. This does not appear to be creating the socially 'mixed community' the initial regeneration plans envisaged. ${ }^{25}$

Stirling Council had promoted what was termed a 'Partnership Area' in the mid i 980 s, which encompassed both Raploch and the 'Top of the Town', entitled Stirling Partnership for Urban Renewal. This resulted in the construction of some new housing, built by Forth Housing Association. A decade and a half of subsequent planning and development work eventually led to its latest incarnation, the Raploch Regeneration Project, which was promoted by a newly created delivery vehicle, the Raploch Urban Regeneration Company Ltd. ${ }^{26}$ Total spend over its ten year programme will exceed $£ 2 \circ$ million, the most significant proportion of which will be for private housing.

In spite of past investments Raploch's unflattering reputation has not only persisted, but, if anything, has worsened. As was noted above, it has also continued to display a social separateness from the rest of Stirling. These constructions of Raploch were achieved by characterising the neighbourhood as Irish, then as mining, and latterly as a place for those that did not work and were welfare dependent. As previously noted, this paralleled 
a longstanding reputation for violence, drunkenness, petty crime and more recently drug related criminality. As a respondent notes:

Raploch was and still is seen as a rough, tough place, a 'cowboy area' in the same way as Fallin, Cowie and Cornton. Interesting that these are all old mining communities (Male key actor 3: Stirling).

This separateness may have been, in part, because Raploch was originally a physically separate village for a long part of its history. It might also have been because Raploch spatially lay immediately behind Orchard House, Stirling's Poor House, now a cottage hospital, in the narrow gap between the Gowanhill and the Forth, on the 'wrong' side of the Castle. This sense of separateness also ensured that Raploch servicemen who died in the First World War were listed separately from those of Stirling. Over the twentieth century, press reports of local crime have tended to refer to a 'Raploch man' as the perpetrator, rather than a 'Stirling man'. Yet, as the recent BBC television series Raploch Lives has shown, people remain proud of their neighbourhood, its strong sense of community and its social distinctiveness. Many families have stayed there over several generations ${ }^{27}$ and large inter-related families have remained a key feature of the Raploch. This, at least, in part, may account for the area's strong sense of community and identity. As a Raploch resident recalls:

The Laffertys had aboot i 5 or I 6 . The Lennon's wis the biggest ah think they were 22 but they had twins an' that tae. Ay the Lennons fae Raploch Road. It wis funny tae see a wee family, ye'd say "that's a queer family, only two bairns." Cos it wis a' big families (Male 63, Raploch).

That said, Raploch, in relation to the rest of Stirling, still remains spatially, socially and culturally separate. As one respondent said:

... you're coming through the grand villas of King's Park and then you're coming round Castle Rock round the King's Knot and then there's Raploch, but there is nothing else, you know, that is the end of Stirling. If you went through it that way and you've got the boundary of the river, you've got the boundary of the old brig coming up to Lawrence Croft there so ... It's geographically identifiable, if you're speaking to somebody from Raploch, where do you come from, Raploch, so I think there is an identifiable area (Male key actor 2: Stirling).

The Raploch: People's Perceptions

Each of the three neighbourhoods examined as part of the Joseph Rowntree Foundation study had their identity established at a very early stage of its history. These neighbourhood identities were underpinned by class and status and proved very resilient to change, with perhaps Raploch being the most striking example. Given this resilience, the initial 
ambitions - both explicitly stated and implicitly understood - set in planning each of these new neighbourhoods proved critical. This finding has important implications for the future planning of new housing developments.

Neighbourhood identity was closely associated with notions of class and status, often constructed from now outdated notions of male employment patterns. In Raploch, this related directly back to mining and labouring, while in Riverside to skilled trades and Randolph Road to the professions. Class, then, is a dominant social identifier for these neighbourhoods.

Not surprisingly perhaps, housing type and tenure were also found to be core in defining a neighbourhood's social identity. Of particular interest to this study was how the advent of the 'Right to Buy' effectively maintained, and then over time exaggerated, the social distinctiveness between what had been originally constructed as two large council estates, Riverside and Raploch. Council housing has almost entirely been sold off in Riverside, leading it to becoming dominated by owner-occupiers, and thus gaining an 'aspirant' label, whereas in Raploch such sales were less common. Rather, the continuation of a needs-based allocations policy contributed to retaining, if not to exaggerating its 'poorer' status.

Interestingly, although there was a marked difference in the denominations of residents in each of the three areas, with Raploch having a significantly higher Catholic population, whereas the other two localities were Church of Scotland, religion failed to emerge as a key marker of social identity and difference, as historically it once did. That said, there were still remnants of anti-Catholic sentiments present which acted as an identifier of difference between Raploch and the other two neighbourhoods.

The relative social positions of Raploch, Riverside and Randolph Road within Stirling had remained stable. Again this is often expressed through the language of class. Thus Raploch has always had a label which identifies it as being 'poor', 'rough', 'coarse' and 'working class', Riverside as 'respectable' and now with the advent of the 'Right to Buy', increasingly 'middle class' and 'aspirational', while Randolph Road was always 'aspirational' and always 'middle class'. These identities had persisted since their original construction, if not before, given the pre existing social identity of the locality in which the housing was built. Again this crucial finding has important implications for the planning of future renewal projects, as well as the creation and subsequent management of new housing developments.

However it is important not to overemphasise historical continuities and the homogeneity of each locality. There was also evidence of long standing internal differentiation within these neighbourhoods, in terms of often minute differences between households, streets and occupational stratification. Each had its own internal dynamic and residents often had their own stories explaining the subtle changes and social gradations within the areas. This was particularly evident in the case of Raploch and Riverside where new housing developments had created noticeable and in some cases quite challenging 
social divisions. The complex and often street-by-street nature of internal neighbourhood differentiation is typified by the following comment from a long-time Raploch resident:

Cos it makes me mad when they say, if yer waitin' they say 'Ye come frae the Raploch' Ah says, 'Excuse me, ah don't come from the Raploch, ah come from the Drip Road'. See we're Drip Road, we're no Raploch. The Raploch is after St Mark's Church. Because when we came here our postal address wis the Drip Road, an ah don't class masel', ah say, 'Drip Road, not Raploch' (Female 86: Raploch).

It was also evident that the external perceptions held about a neighbourhood's identity were stronger and more in caricature, than those held by people who actually lived in the particular neighbourhood. Residents perceived greater internal social diversity than the homogeneity portrayed by 'outsiders'. As one interviewee commented:

I suppose it means like people have got a lot of expectations of you when they find that you come frae the Raploch and people think that you're hard and that you'll fight them and that you're ... from a rough area and ... people think it's a really bad area but like it isnae really as bad as people think. I think it's just had a lot of hype behind it but I suppose people just assume that you, you're kind of unemployed or in a rubbish job or ... you've got three weans tae four different, well three different guys or whatever... It's no' the place I want to spend the rest of my life like but it's no' that I think it's a really bad place to live, it's just that like I've grew up there all my life and it's no' the best place in the world to live either (Female 22: Raploch).

In each of the three different neighbourhoods studied, family networks, friends and neighbours were accorded varying degrees of importance in the construction and sustaining of community. While different people gave a varying emphasis to the importance of these three categories, there was a general recognition that, as a whole, their presence helped sustain a sense of community and people's own individual sense of attachment to place and involvement in that community. As one respondent suggests:

Friends, neighbours and family all play a part in creating a sense of community. It's often about creating links, relations with the small block of people around you. In a new estate it can be a case of getting out a bottle of wine and finding some common cause. Within Raploch the common cause is the stigma that attaches to the place, it tends to bind people together. People have a tendency to stick to their own. We get trainees in here doing school or college placements, most know little about Stirling, but everyone of them has heard about Raploch, Mags Hainey, drugs and it being a rough place. I listen for a while and then tell them I was born and brought up there. Their reactions are interesting (Male key actor I : Stirling).

The core roles played by women in both home and family were also seen as critical to sustaining community, through facilitating child rearing activities that helped foster a sense 
of community. As one woman recalled of her school days, 'And eh, a' the mothers, if you lived near enough - and most of us did live near enough - they used to come up to the school gates and that wi' a play-piece fur ye (laughs).' (Female 73: Raploch).

Women, in pursuing family and child rearing roles contributed greatly to the communications traffic that created this sense of community. Many of the respondents perceived a decline of such networking given the increasing numbers of working women. Not having women around during the day, undertaking domestic and family chores, playing with their children and being out on the street had diminished a particular understanding of community.

The role played by older people in relation to construction of community was also considered important, but for slightly different reasons. They often provided a degree of historic continuity for a neighbourhood, given their ability to connect directly with the past history of the place. Often this could be best described as an 'imagined community', of an idealised memory. At the same time, because their social world was focussed at the local scale, very often in the past and now more so currently, they also played a similar role to women of school-age children in being part of the local presence which helped emphasise a sense of community.

It seems that what was understood as 'community' was often rooted in this realm of the familiar but mundane and everyday interactions - chatting at the Post Office or hairdressers and conversations related to the school, the bowling club and suchlike. Community was constructed through this myriad of intangible and fleeting, routine and mundane interactions in various localised settings. These were often enough to give people a strong sense of community and a powerful sense of attachment and belonging. This sense of community was also found to be very fragile and could be lost or gained with very subtle changes to how residents perceived any alteration to their surroundings. For example, with the loss of the Post Office or local shops, the opportunity to engage in a range of social interactions is reduced because the opportunities for chance meetings become fewer. Again these have important implications for those charged with improving old, or creating new housing neighbourhoods.

Finally, there emerged an apparent irony in all this work: the most aspirational neighbourhood in this study, Randolph Road, was found to have no obvious community focus, or sense of community among its residents. As people get richer, they may move into a more individualised or atomised setting: places where community is largely absent. The social networks and connections of these residents link to a much wider social world, not merely the local neighbourhood or Stirling. Elements of this pattern were evident within Riverside, and to a much lesser extent in Raploch. Yet despite all this, it still appears that we still hanker after some notion of community and belonging, thus place identity and a sense of attachment and belonging are still important individually and collectively. 
The Raploch: The Future

Overall, the study revealed that Raploch had long experienced social distance and separateness: in that it was composed of the 'wrong' class and many were also the 'wrong' religion. Hence, the housing that emerged was both grudging and functional, as was the subsequent quality of housing service and community facilities provided to the local community. The Raploch Urban Regeneration Project has as a stated ambition, the creation of a socially 'mixed community'. One part of this ambition is the construction of a new community campus, where the previous Catholic and Non Denominational Primary schools will share the same school building. Similarly, the 'mixed community' will be a blend of old council housing and newly constructed private housing. Drip Road, now denied its arterial route status into Stirling, will separate these two entities. From the evidence presented in the Joseph Rowntree Foundation research, we expect the reality that will emerge will be a far more socially polarised community. In the past social differences did exist within Raploch, even if outsiders perceived it as a relatively uniform poor community. But in the future, however, the internal social polarisation will be far more exaggerated and social mixing will remain a dream. Class divisions will be far more exaggerated and marked.

Yet Raploch has always been a socially stigmatised place. Perhaps the earliest reference in literature to the Raploch appears in Sir David Lyndsay's famous play, Ane Pleasant Satyre of the Thrie Estaitis written in the I 55 os. His mention of a quality coat made of 'Raploch grey' in the context of this play was satirically implying poor quality and coarseness. ${ }^{28}$ Jamieson's Dictionary of i 808 notes Raploch was a 'coarse woollen cloth, made from the worst kind of wool, homespun, and not dyed.' So, as an adjective, Raploch implied rough and coarse, which Robert Burns makes explicit in his poem, Second Epistle to Davie Sillar, where he writes:

\author{
The Muse, poor hizzie \\ Tho' rough and raploch be her measure \\ She's seldom lazy
}

Raploch has long been a place where social distance has been located; a place apart, a place of poverty which lay directly behind the town's Poor House. Today it is the place that lies immediately behind the Homeless Persons Unit. The limited ambitions set for the r 930 s slum clearance housing have played out over the last eighty years, in the life experiences of those who have lived there. Remedying this lack of ambition, however, will take a great deal more than mere physical and associated social engineering. Rather it needs to address deep-seated notions of class and discrimination.

\title{
AC K N OW LEDGEMENTS
}

We would like to acknowledge the support of the Joseph Rowntree Foundation for their support for this work, and the work of Fay Oliver in undertaking the historical research. 


\section{Notes}

I. A. Ravetz, Council Housing and Culture: The history of a social experiment, London, $200 \mathrm{I}$, p. 2.

2. A. Gibb, 'Policy and politics in Scottish housing since 1945', in Richard Rodger (ed.), Scottish Housing in the Twentieth Century, Leicester, I989, pp. I 77-80.

3. D. Robertson and J. Smyth, 'L'évolution du logement social en Écosse: de la norme à la marge', in V. Laflamme, C. Levy-Vroelant, D. Robertson, J. Smyth (eds), Le logement precaire en Europe, Paris, 2007, pp. 63-84.

4. D. Robertson, J. Smyth and I. McIntosh, Neighbourhood Identity: People, time and place, Joseph Rowntree Foundation, York, 2008. http://www.jrf. org.uk/bookshop/details.asp?pubID $=946$

5. The precise figure was $1,062,744$. Over the same period the private sector built 3 1 9,500 homes. I 978 was the year when the number of completions by the private sector eventually surpassed that by the public sector. Figures taken from Rodger, Scottish Housing, pp. $236-7$.

6. C. Mair, Stirling: The Royal Burgh, Edinburgh, I 995, p. I 76.

7. PP 1870 , Commission on the Employment of Children, Young Persons and Women in Agriculture, Fourth Report, Appendix Part II, Evidence from the Assistant Commissioners; Stirling Observer, I August 1872.

8. Stirling Observer, i August I 872 .

9. The four data zones that make up Raploch from the Scottish Government's Neighbourhood statistics are all in the more deprived deciles for Scotland overall, revealing major problems in relation to income, employment, health and educational attainment thus highlighting severe household deprivation: see D. Robertson, et al., 2008, op cit. pp. 32-33.

ı o. PP I 908 Housing Conditions (Scotland). Based on the census of I 90 I, in the Scottish burghs of over 10,000 persons almost half the population lived more than two to a room, whereas in Stirling the proportion was 35 per cent.

I I. Royal Burgh of Stirling Council Minutes, i6 December 1918, Stirling Council Archive, $\mathrm{SB}_{\mathrm{I}} / \mathrm{I}$.

I 2. Royal Burgh of Stirling Council Minutes, 29 October 1920, Stirling Council Archive, $\mathrm{SB}_{\mathrm{I}} / \mathrm{I}$.

I 3. These houses were built under the terms of the much more generous i 9 I 9 , or Addison, Act. The Lloyd George Government quickly retreated from this provision meaning that few houses were actually constructed under this Act, but they were 'completed to the high standards of the Tudor Walters Committee.' J. Melling, 'Clydeside Rent Struggles and the making of Labour politics in Scotland I 900-39' in Rodger, Scottish Housing, pp. 72-75.

I4. In early I 928 , a Labour councillor proposed that Stirling Council send a deputation to the Scottish Board of Health, 'to urge that houses of a rental more in accordance with the ability of the working classes to pay should now be erected.' Royal Burgh of Stirling Council Minutes, i 7 January i 929, Stirling Council Archives, $\mathrm{SB}_{\mathrm{I}}$ / I. 
I 5. Royal Burgh of Stirling Housing Committee Minutes, 30 November I 925 , Stirling Council Archive, $\mathrm{SB}_{\mathrm{I}} / \mathrm{I}$.

I6. Royal Burgh of Stirling, Drip Road Housing Scheme No 2 Site Plan, 7 October 1927, Stirling Council Archive SB4 3 I 2 I 9 I 5 Site Plan.

I 7. Royal Burgh of Stirling, Housing Committee Minutes, 26 May i 930, Stirling Council Archive, $\mathrm{SB}_{\mathrm{I}} / \mathrm{I}$.

I 8. The Scotsman, 8 June 1933.

19. Stirling Journal and Advertiser, 23 January 1936.

20. Stirling Observer 150 Years On, Stirling, 1986, p. 28. Dictionary of Scottish Architects 1840-1980, entry for Eric Sinclair Bell (Captain), www.scottish architects.org.uk

2 I. Royal Commission on Housing in Scotland, Report of the Royal Commission on the Housing of the Industrial Population of Scotland Rural and Urban (Cd. 8731). Edinburgh, I 9 I 7 .

22. Scottish Development Department, Non Traditional Housing in Scotland, Edinburgh, 1996.

23. The Architects' Journal, 20 June i 973 , p. I 498.

24. Raploch Urban Regeneration Company Ltd., Raploch: Developing a 21st century community. Stirling, 2004.

25. Stirling Partnership for Urban Renewal, Social Survey of Raploch, Stirling, 2000.

26. Raploch Urban Regeneration Company Ltd., op cit.

27. The Herald, 2 September 2006.

28. We would like to thank Elspeth King for keeping us right in our interpretation of this reference. 